\title{
Fertility in an XY/XXY Male Married to a Translocation Heterozygote*
}

\author{
W. M. COURT BROWN, D. J. MANTLE, KARIN E. BUCKTON, and ISHBEL M. TOUGH
}

From the Medical Research Council Clinical Effects of Radiation Research Unit, Western General Hospital, Edinburgh

The question has arisen of whether subjects showing the features of seminiferous tubular dysgenesis (Klinefelter's syndrome) may sometimes be fertile. Frøland and Ullrich (1962, personal communication) studied one such subject, who had an $\mathrm{XY}$ XXY sex chromosome complement and who claimed to have had 2 children. Blood group studies on the propositus, his wife, and his surviving son, showed that the probability of the propositus being the father of the son was 6 times that of a male from the general population. Kaplan, Aspillaga, Shelley, and Gardner (1963) published data on another male with the features of seminiferous tubular dysgenesis who claimed to have had 7 children by 3 wives. The sex chromosome complement of cells from a blood culture was XXY. As blood group studies could not be done the claim to paternity could not be substantiated. Lennox (1963) quotes 4 subjects with seminiferous tubular dysgenesis who claimed to have had children, but on investigation none of these claims was shown to be valid.

We have now had the opportunity of studying altogether 140 males with an abnormal sex chromosome complement, a number of whom have been children or adolescents and a number who have been unmarried adults. Of 42 adults known to have been married, 5 have been said to have had children. In only $\mathrm{I}$ instance, however, has investigation supported the claim to paternity. This subject, who with his wife and family is the subject of this report, has an $\mathrm{XY} / \mathrm{XXY}$ sex chromosome complement. There is considerable added interest, however, because not only did the propositus have one unusually large autosome 16 , but his wife was found to be a translocation heterozygote.

\section{Family Data}

The pedigrees of the propositus and his wife are shown in Fig. I. Several deaths have occurred in both

\footnotetext{
* Received October 14, 1963.
}

families, and these together with the relevant certified causes of death are shown in Table I.

There is some doubt about the conceptional history of the wife of the propositus. One problem arose through her claim that III.2 and III.3 were a twin pair, and that III.2 was aborted early in the pregnancy. The hospital obstetrical notes relating to the delivery of III.3 provide no evidence to support this claim, and III.2 and III.3 are regarded as the products of separate pregnancies. The same hospital notes refer to the wife having had 2 full-term male children before her marriage. She has not, however, volunteered this information herself, and no record can be found of the birth of these 2 children in Scotland.

\section{Clinical Data}

The propositus was admitted to a hospital for mental disease at the age of $\mathbf{5 2}$ with paranoid schizophrenia. He has remained in hospital ever since, and he was identified in 1962 as being chromatin positive during a routine survey of patients in hospitals for mental disease. In a buccal smear $52 \%$ of cells contained a single sex chromatin body, while there were 7 drumsticks and 3 sessile appendages in 500 polymorphonuclear leucocytes. At his birth both his parents were 28 years of age.

II
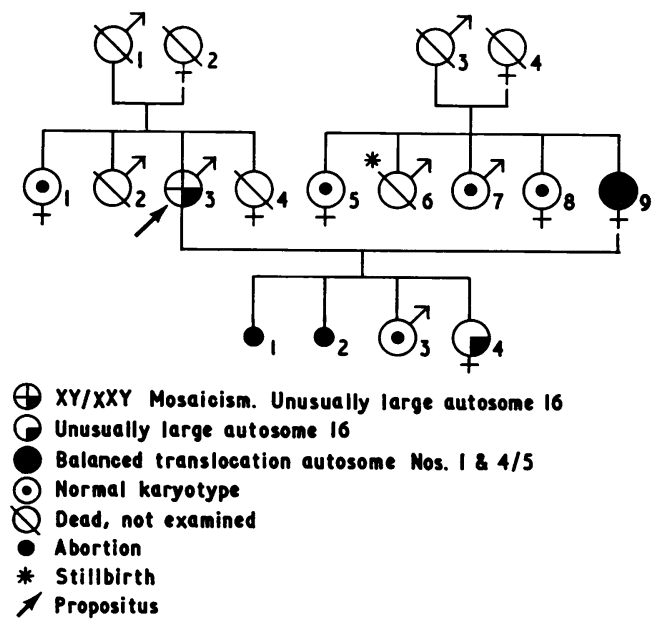

FIG. I. Pedigree of propositus and his wife. 
TABLE I

DETAILS OF PEDIGREE SHOWN IN FIG. I

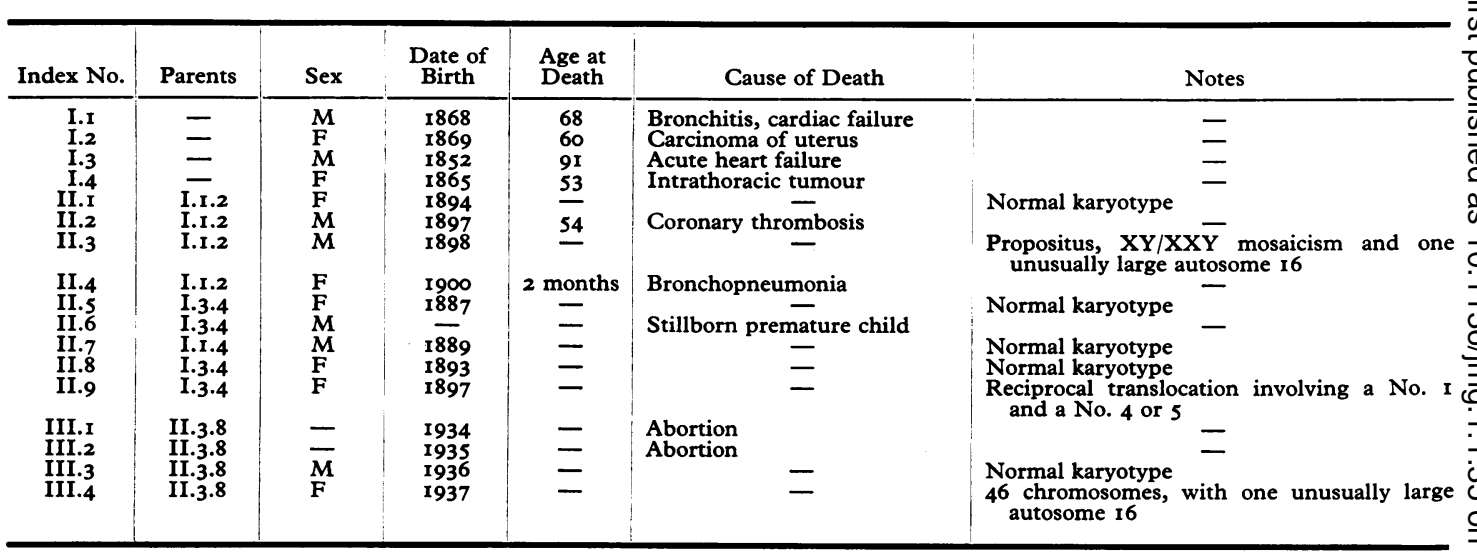

TABLE II

CYTOGENETIC RESULTS ON THE PROPOSITUS

\begin{tabular}{|c|c|c|c|c|c|c|}
\hline \multirow{2}{*}{ Tissue } & \multicolumn{5}{|c|}{$\begin{array}{l}\text { Number of Cells With Chromosome } \\
\text { Counts of }\end{array}$} & \multirow{2}{*}{$\begin{array}{l}\text { Total } \\
\text { Cells }\end{array}$} \\
\hline & $<45$ & 45 & 46 & 47 & $>47$ & \\
\hline $\begin{array}{l}\text { Blood } \\
\text { Skin }\end{array}$ & 二 & I & $\begin{array}{l}17 \\
20\end{array}$ & $\begin{array}{l}32 \\
10\end{array}$ & 二 & $\begin{array}{l}50 \\
30\end{array}$ \\
\hline
\end{tabular}

I 5 of the blood cells with 46 chromosomes had an XY complement and all the cells with 47 chromosomes an XXY complement. 18 of the skin cells with 46 chromosomes had an XY complement and all the cells with 47 chromosomes had an XXY complement.
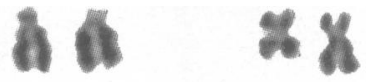

$111 \cdot 4$
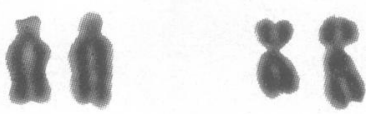

$111 \cdot 3$

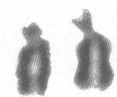

13

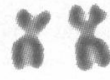

16
FIG. 2. Autosome pairs nos. 13 and 16 from II.3, III.3, and III.4.
Examination showed his penis and scrotum to be normally developed. The left testis was small, about $1.5 \mathrm{~cm}$. in length, and soft in consistency, while a hydrocele made examination of the right testis impossible. There was no gynaecomastia, and his facial, axillary, and pubic hair showed a normal male development. His height was $165 \mathrm{~cm}$., his arm-span being $167.5 \mathrm{~cm}$. From crown to pubis he measured $84 \mathrm{~cm}$. and from pubis to sole $8 \mathrm{I} \mathrm{cm}$. There was no colour vision defect on testing with Ishihara cards.

The wife of the propositus was not medically examined, but she appeared normally developed, and there is no record of her having had any major illness. The son also appeared normal, but the daughter suffers from hebephrenic schizophrenia.

\section{Cytogenetic Data}

Chromosome studies have been done on blood cultures from all the living members of both families, while studies on skin fibroblast cultures have also been done for the propositus (II.3, Fig. I). The count distributions on the blood and skin cultures of the latter are shown in Table II. It is clear from these and the results of nuclear sexing that he has a mosaic sex chromosome complement of the XY/XXY type. A further feature was that all his cells showed one member of pair 16 to be larger than the other, being at least as long as a No. 13 and occasionally longer. In addition the centromere of the affected $\mathrm{O}$ chromosome was more submetacentric in position than usual. Autosome pairs Nos. 13 and 16 are shown in Fig. 2 for the propositus (II.3), for III.3, and for III.4. The frequency with which this familial phenomenon $\underset{\gamma}{ }$ occurs is currently being studied in Edinburgh on a random sample of the general population.

The wife of the propositus (II.9) had a normal count distribution, but analysis of her cells showed a constant abnormality to be present (Fig. 3). There was only one normal autosome No. I and only three members of 

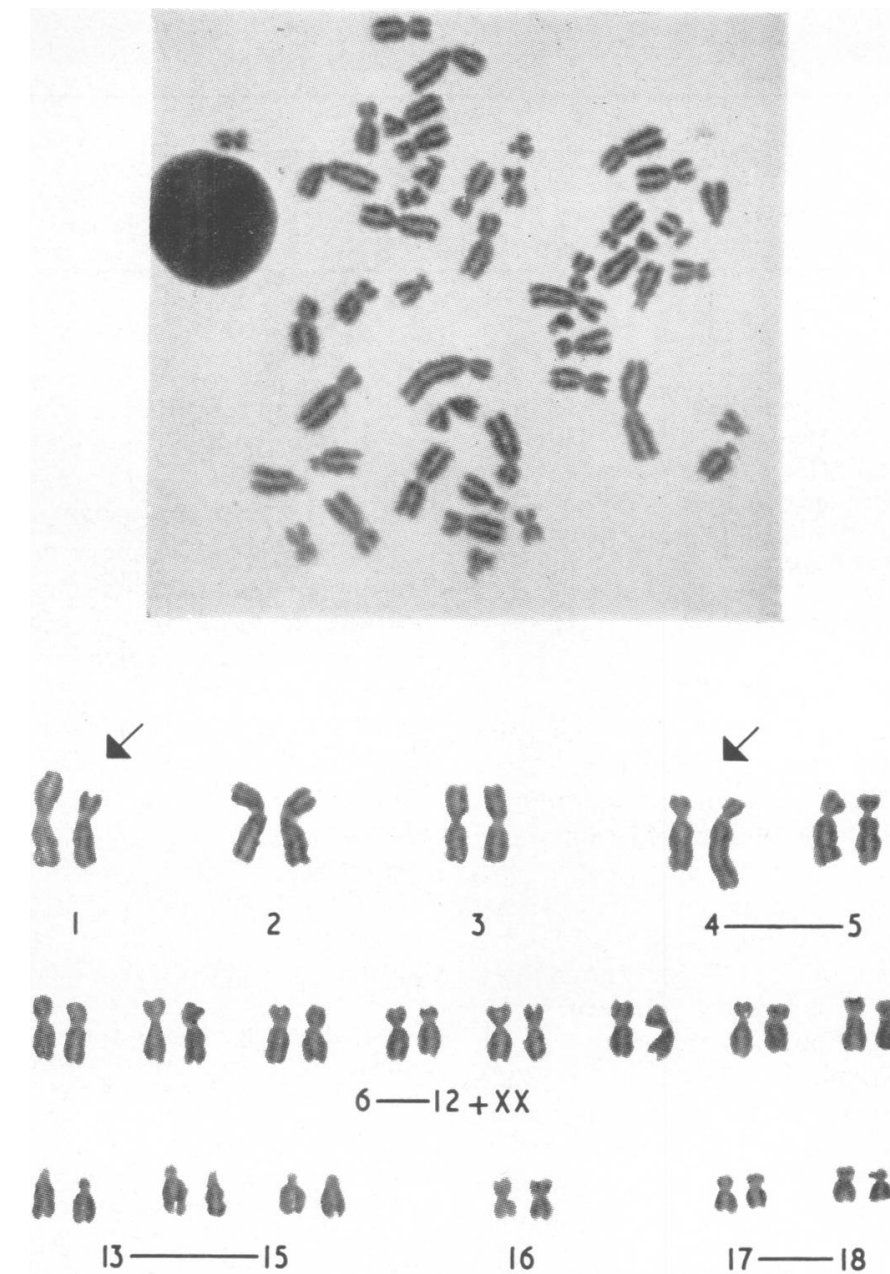

3

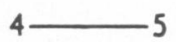

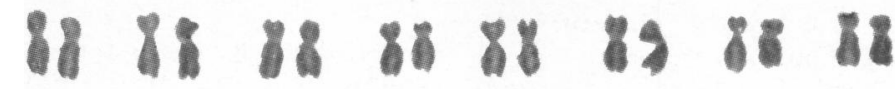 \\ $6-12+x x$}

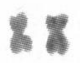

16
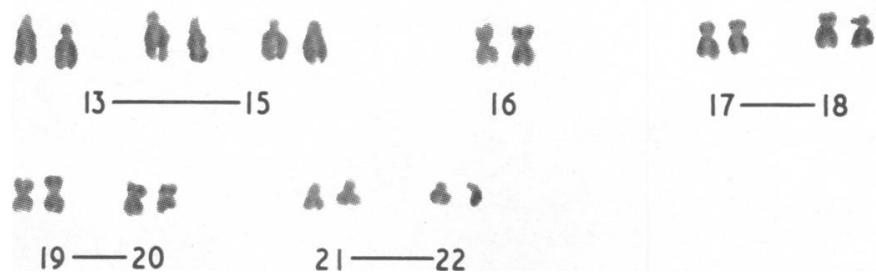

FIG. 3. Cell and karyotype from II.9.

group $4 / 5$ present. There was an abnormally large submetacentric chromosome and also an additional chromosome in the medium-size range. These latter 2 chromosomes are interpreted to be the result of a reciprocal translocation between an autosome No. I and a member of group 4/5. Additional evidence for this interpretation is that the extra chromosome in the medium-size range had in many cells a secondary constriction characteristic both in type and position of that of an autosome No. $I$.

The daughter of the propositus (III.4) had a normal count distribution, but analysis of her cells showed that she also had the unusually large autosome I6 (Fig. 2).
For all other subjects studied the chromosomes were indistinguishable from normal (II.I, II.5, II.7, II.8, and III.3).

\section{Blood Group Studies}

The results of blood group studies are shown in Table III. Considering the blood groups of the mother (II.9) and her son (III.3), the propositus had to have $\mathrm{O}, \mathrm{Ms}$, $R_{2}, k, F y^{a}$, and $\mathrm{Jk}^{\mathrm{a}}$ if he was the father. The chance of a random sperm from a white man having the genes for these antigens is $0.006 \mathrm{r}$. As the propositus had these 
TABLE III

BLOOD GROUP STUDIES

\begin{tabular}{|c|c|c|c|c|c|c|c|c|c|c|}
\hline Pedigree No. & ABO & MNS & $\mathbf{R h}$ & $\mathbf{K}$ & $\mathrm{Xg}_{\mathbf{g}}$ & $\mathbf{P}$ & Fy & Jk & $\mathrm{Lu}$ & Le \\
\hline $\begin{array}{l}\text { II. } 3 \\
\text { II. } 9 \\
\text { III. } \\
\text { III. } 4\end{array}$ & $\begin{array}{l}0 \\
0 \\
0 \\
0\end{array}$ & $\begin{array}{l}\text { MSMs } \\
\text { MsNs } \\
\text { MsMs } \\
\text { MSMs }\end{array}$ & $\begin{array}{c}\mathbf{R}_{2} \mathbf{r} \\
\mathbf{R}_{1}^{\mathbf{W}} \mathbf{R}_{2} \\
\mathbf{R}_{1} \mathbf{R}_{2} \\
\mathbf{R}_{2} \mathbf{R}_{2}\end{array}$ & $\begin{array}{l}\mathbf{k k} \\
\mathbf{k k} \\
\mathbf{k k} \\
\mathbf{k} \mathbf{k}\end{array}$ & $\begin{array}{l}a+ \\
a+ \\
a+ \\
a+\end{array}$ & $\begin{array}{l}\mathbf{P}_{1}+ \\
\mathbf{P}_{1}+ \\
\mathbf{P}_{1}+ \\
\mathbf{P}_{\mathbf{1}}+\end{array}$ & $\begin{array}{l}\mathbf{a}+\mathbf{b}+ \\
\mathbf{a}-\mathbf{b}+ \\
\mathbf{a}+\mathbf{b}+ \\
\mathbf{a}+\mathbf{b}+\end{array}$ & $\begin{array}{l}a+ \\
a-b+ \\
a+b+ \\
a+b+\end{array}$ & $\begin{array}{c}* \\
a- \\
a- \\
a-\end{array}$ & $\begin{array}{c}* \\
\mathbf{a}-\mathbf{b}+ \\
\mathbf{a}-\mathbf{b}+ \\
\mathbf{a}-\mathbf{b}-\end{array}$ \\
\hline
\end{tabular}

* Not tested.

genes his chance of being the father of III.3 is ro times that of a random man. Considering the groups of the mother and her daughter (III.4) the propositus had to have $\mathrm{O}, \mathrm{MS}, \mathrm{k}, \mathrm{R}_{2}, \mathrm{Fy}^{\mathrm{a}}$, and $\mathrm{Jk}^{\mathrm{a}}$ if he was the father. The chance of a random sperm from a white man having the genes for these antigens is 0.0047 . As the propositus had these genes his chance of being the father of III.4 is 13 times that of a random man.

\section{Discussion}

The evidence from the blood group studies supports the contention that the propositus is the father of III.3 and III.4, and this is not contradicted by the study of haptoglobin and transferrin types, all four subjects having the same haptoglobin type (2-2) and transferrin type (c). Additional support for the propositus being the father of III.4 is derived from the finding that both showed one member of pair 16 to be larger than the others. It is probably significant that the propositus has an $\mathrm{XY} / \mathrm{XXY}$ sex chromosome complement. If in such a person some of the cells in the primitive gonads have an XY complement, there seems, on theoretical grounds, to be no bar to normal post-pubertal development at least in a proportion of testicular tissue.

The other interesting finding in the study of this family was that the wife of the propositus was a translocation heterozygote. There are no published data available on the frequency of structural heterozygotes in the human population, but Jacobs, Brunton, and Court Brown (1964) in a study of a random sample of 188 subjects of ages 65 and more drawn from the general population found one translocation heterozygote. It is important to attempt to obtain more definitive data on this subject so as to define the size of the pool of subjects in the general population who are balanced structural heterozygotes, involving translocations and inversions. A proportion of the zygotes conceived by such subjects may carry unbalanced amounts of genetic material, and a consequence of this may be death of the zygote, or of the embryo, or of the foetus, or the presence of congenital malformations in postnatal life. This may well explain the fact that the wife of the propositus had had 2 abortions.

\section{Summary}

A schizophrenic patient is described who has the features of seminiferous tubular dysgenesis together with a sex chromosome complement of XY/XXY. A further feature is that he also has an unusually large autosome No. I6. The wife of the patient is a translocation heterozygote, an autosome No. I being involved together with a member of group 4/5. The wife has had 2 live-born children since her marriage, a son and a daughter, and blood group studies support the contention that the patient is the father. Further support for this in respect of the daughter is derived from the finding that she also has an unusually large autosome No. 16.

We would like to thank Dr. R. R. Race for his advice and the staffs of the M.R.C. Blood Group Research Unit and the M.R.C. Human Biochemical Genetics Unit for their help. Dr J. W. Affleck and Dr A. D. Forrest, of the Royal Edinburgh Hospital, have kindly allowed us to publish details of the propositus and his daughter who are under their respective care. Finally, we are grateful for the help of the following members of the staff of M.R.C. Clinical Effects of Radiation Research Unit: Mrs Jane Bond, Miss Muriel Brunton, Miss Eileen Inglis, Miss Patricia Jacobs, Mr Alan Ross, and Miss Gillian Woodcock.

\section{Note Added in Proof}

Details of the propositus have also been published as Case No. 9/62 (p. I2I) in 'Abnormalities of the Sex Chromosome Complement in Man' by Court Brown, Harnden, Jacobs, Maclean, and Mantle (I964).

\section{REFERENCES}

Court Brown, W. M., Harnden, D. G., Jacobs, P. A., Maclean, N., and Mantle, D. J. (1964). Abnormalities of the Sex Chromosome Complement in Man. Spec. Rep. Ser. med. Res. Coun. (Lond.), No. 305

Jacobs, P. A., Brunton, M., and Court Brown, W. M. (1964). Cytogenetic studies on the general population: subjects of 65 years and more. Ann. hum. Genet. In the press.

Kaplan, H., Aspillaga, M., Shelley, T. F., and Gardner, L. I. (I963). Possible fertility in Klinefelter's syndrome. Lancet, I, 506.

Lennox, B. (1963). Possible fertility in Klinefelter's syndrome. ibid. $\mathrm{x}, 6 \mathrm{II}$. 